\title{
STUDI TENTANG PARTISIPASI PESERTA DIDIK KELAS VIII DALAM KEGIATAN EKSTRAKURIKULER PADA SENI BUDAYA TARI DI MADRASAH TSANAWIAH NEGERI KOTA TERNATE
}

\author{
Nuraisyah I. Adam ${ }^{1}$ dan Hasmawati ${ }^{2}$ \\ ${ }^{1}$ Alumni Prodi Pendidikan Pancasila dan Kewarganegaraan, FKIP Universitas Khairun, Jl. Bandara Baabullah Akehuda \\ Ternate Utara, 97728, Indonesia \\ ${ }^{2}$ Dosen Prodi Pendidikan Pancasila dan Kewarganegaraan, FKIP Universitas Khairun, Jl. Bandara Baabullah Akehuda Ternate \\ Utara, 97728, Indonesia
}

Author Correspondence: hasmawati@yahoo.com

$\begin{array}{ll}\text { Diterima } & : 20-03-2018 . \\ \text { Direvisi } & : 30-03-2018 \\ \text { Dipublikasi } & : 05-04-2018\end{array}$

\begin{abstract}
This research is motivated by an activity to foster the talents, interests and skills of students in the school, which are called extracurricular activities in cultural arts and dance. This study aims to determine the form of student participation in extracurricular activities in dance culture, as well as factors that inhibit the participation of students in extracurricular activities in dance culture. This study uses a type of descriptive qualitative research aimed at gaining a general understanding of social reality from a participant's perspective. The technique of collecting data through observation, interviews, and documentation. The data is analyzed using Data Reduction, Data Presentation, and Verification of Data and conclusions scientifically. The results of this study indicate the form of student participation in extracurricular activities in dance culture arts. The number of eighth grade students in the MTs Negeri Kota Ternate Ternate is 219 students. Only 50 students participated in extracurricular activities. This shows that the participation of students in extracurricular activities is very minimal. Because students are less interested and less like extracurricular activities in dance culture. Factors that hinder the participation of students in extracurricular activities in dance culture are mostly male students who feel inferior to participate in extracurricular activities in the field of dance culture, this is due to male students assume that extracurricular activities in dance culture are especially for female students. So that students who take extracurricular activities in the art of dance culture are mostly female students compared to male students.
\end{abstract}

Keywords: extracurricular activities, dance culture, learners, participation

\section{PENDAHULUAN}

Pembelajaran merupakan suatu proses secara sistematis, artinya di dalam pembelajaran terkandung beberapa komponen yang saling berkaitan dan mendukung untuk mencapai tujuan pembelajaran tertentu. Inti dari pembelajaran tidak lain adalah kegiatan belajar siswa dalam mencapai suatu tujuan pembelajaran. Belajar mengajar merupakan dua konsep yang tidak dapat dipisahkan antara satu dengan yang lainnya. Apabila ditinjau dari asal katanya, proses belajar mengajar terdapat dua kegiatan, yaitu belajar dan mengajar. Belajar dapat diartikan sebagai perubahan tingkah laku pada individu berkat adanya interaksi antara individu dengan lingkungan. (Uzer Usman dan Lilis Setiawati,1995:4).

Menurut Mukminin (1998:5), pembelajaran merupakan padanan kata dari kata instructions, yang berarti membuat orang belajar. Pengertian lain dari pembelajaran dapat diartikan sebagai proses belajar mengajar (KBBI, 1994:14) yang mempunyai aspek penting yaitu bagaimana siswa dapat aktif mempelajari materi pelajaran yang disajikan sehingga dapat dikuasai dengan baik. Menurut UU Sistem Pendidikan Nasional No. 20 bab 1 pasal 1 ayat 20 tahun 2003 menjelaskan pendidik dan sumber belajar pada suatu bimbingan belajar. Jadi pembelajaran adalah kegiatan belajar secara riil di dalam kelas. Proses belajar mengajar merupakan rangkaian kegiatan (dalam hal-hal tertentu juga siswa) mulai dari perencanaan, pelaksanaan dan penilaian program pengajaran. Pembelajaran terdiri dari beberapa komponen, yaitu siswa, guru, tujuan, meteri, metode, media, dan evaluasi. Komponen- 
komponen tersebut saling berkaitan dan saling menunjang dalam rangka mencapai tujuan pembelajaran.

Sardiman,(2005:125). Mengemukakan guru adalah salah satu komponen manusiawi dalam proses belajar mengajar yang ikut berperan dalam usaha pembentukan sumber daya manusia yang potensial dibidang pembangunan. Oleh karena itu, guru yang merupakan salah satu unsur dibidang kependidikan harus berperan secara aktif dan menempatkan kedudukannya sebagai tenaga profesional, sesuai dengan tuntutan masyarakat yang semakin berkembang. Dalam hal ini guru tidak semata-mata sebagai pengajar yang melakukan transfer ilmu pengetahuan, tetapi juga sebagai pendidik yang melakukan transfer nilainilai moral sekaligus sebagai pembimbing yang memberikan pengarahkan dan menuntun siswa dalam belajar.

Kegiatan Ekstrakurikuler di sekolah seharusnya diminati oleh setiap peserta didik, bahwasannya kegiatan ekstrakurikuler juga erat hubungannya dengan prestasi belajar peserta didik. Melalui kegiatan ekstrakurikuler peserta didik dapat bertambah wawasan mengenai mata pelajaran yang erat kaitannya dengan pelajaran di ruang kelas dan biasanya yang membimbing peserta didik dalam mengikuti kegiatan ekstrakurikuler adalah guru bidang studi yang bersangkutan. Melalui kegiatan ekstrakurikuler juga peserta didik dapat menyalurkan bakat, minat dan potensi yang dimiliki. Salah satu ciri kegiatan ekstrakurikuler adalah keanekaragamannya, hampir semua minat remaja dapat digunakan sebagai bagian dari kegiatan ekstrakurikuler.

Kegiatan ekstrakurikuler adalah kegiatan di luar jam pelajaran sekolah biasa, yang dilakukan di sekolah dengan tujuan untuk memperluas pengetahuan peserta didik, mengenai hubungan antar mata pelajaran, menyalurkan bakat dan minat, serta melengkapi pembinaan manusia seutuhnya. Kegiatan ini dilakukan berkala atau hanya dalam waktu-waktu tertentu dan ikut dinilai. (Saputra, 1998:6).

Ekstrakurikuler adalah kegiatan yang dilakukan oleh peserta didik sekolah atau universitas, di luar jam belajar kurikulum standar. Kegiatan-kegiatan ini ada pada setiap jenjang pendidikan dari sekolah dasar sampai universitas. Kegiatan ekstrakurikuler ditujukan agar peserta didik dapat mengembangkan kepribadian, bakat, dan kemampuannya diberbagai bidang di luar bidang akademik. Kegiatan ini diadakan secara swadaya dari pihak sekolah maupun peserta didik itu sendiri untuk merintis kegiatan di luar jam pelajaran sekolah.

Kegiatan ekstrakurikuler merupakan kegiatan pengayaan dan perbaikan yang berkaitan dengan program kokurikuler dan intrakurikuler. Kegiatan ini dapat dijadikan sebagai wadah bagi peserta didik yang memiliki minat mengikuti kegiatan tersebut. Melalui bimbingan dan pelatihan guru, kegiatan ekstrakurikuler dapat membentuk sikap positif terhadap kegiatan yang diikuti oleh para peserta didik. Kegiatan ekstrakurikuler yang diikuti dan dilaksanakan oleh peserta didik baik disekolah maupun diluar sekolah, bertujuan agar peserta didik dapat memperkaya dan memperluas diri. Memperluas diri ini dapat dilakukan dengan memperluas wawasan pengetahuan dan mendorong pembinaan sikap atau nilai-nilai.

Ekstrakurikuler erat hubungannya dengan prestasi belajar peserta didik. Melalui kegiatan ekstrakurikuler peserta didik dapat bertambah wawasan mengenai mata pelajaran yang erat kaitannya dengan pelajaran di ruang kelas dan biasanya yang membimbing peserta didik dalam mengikuti kegiatan ekstrakurikuler adalah guru bidang studi yang bersangkutan. Melalui kegiatan ekstrakurikuler juga peserta didik dapat menyalurkan bakat, minat dan potensi yang dimiliki. Salah satu ciri kegiatan ekstrakurikuler adalah keanekaragamannya, hampir semua minat remaja dapat digunakan sebagai bagian dari kegiatan ekstrakurikuler.

Meningkatkan keterampilan pada peserta didik, maka diadakan suatu kegiatan untuk membina bakat, minat, dan keterampilan peserta didik. Kegiatan untuk membina keterampilan peserta didik di sekolah dinamakan dengan ekstrakurikuler. Ekstrakurikuler di sekolah memiliki peran yang mulia, dimana dalam kegiatan tersebut terkandung suatu proses untuk membina bakat, minat, keterampilan peserta didik memacu ke arah kemampuan mandiri, percaya diri dan kreatif.

Partisipasi peserta didik dalam pembelajaran sangat penting untuk menciptakan pembelajaran yang aktif, kreatif, dan menyenangkan. Dengan demikian tujuan pembelajaran yang sudah direncanakan 
bisa dicapai semaksimal mungkin. tidak ada proses belajar tanpa partisipasi dan keaktifan anak didik yang belajar. Setiap anak didik pasti aktif dalam belajar, hanya yang membedakannya adalah kadar/bobot keaktifan anak didik dalam belajar. Ada keaktifan itu dengan kategori rendah, sedang dan tinggi. Di sini perlu kreatifitas guru dalam mengajar agar peserta didik berpartisipasi aktif dalam pembelajaran. Penggunaan strategi dan metode yang tepat akan menentukan keberhasilan kegiatan belajar mengajar. Hasil yang dicapai peserta didik setelah mengikuti pelajaran ekstrakurikuler dan berdampak pada hasil belajar di ruang kelas yaitu pada mata pelajaran tertentu yang ada hubungannya dengan ekstrakurikuler yaitu mendapat nilai baik pada pelajaran tersebut. Biasanya peserta didik yang aktif dalam kegiatan ekstrakurikuler akan terampil dalam berorganisasi, mengelola, memecahkan masalah sesuai karakteristik ekskul yang digeluti. Berpijak dri uraian di atas maka pertanyaan yang diajukan dalam tulisan ini adalah bagaimana partisipasi peserta didik kelas VIII dalam kegiatan ekstrakurikuler pada seni budaya tari di Madrasah Tsanawiah Negeri Kota Ternate.

\section{METODE PENELITIAN}

Tipe penelitian yang digunakan dalam penelitian ini adalah tipe penelitian kualitatif deskriptif. Penelitian kualitatif deskriptif adalah bertujuan untuk mendapatkan pemahaman yang sifatnya umum terhadap kenyataan sosial dari perspektif partisipan. Pemahaman tersebut tidak ditentukan terlebih dahulu, tetapi didapat setelah melakukan analisis terhadap kenyataan sosial yang menjadi fokus penelitian. Berdasarkan analisis tersebut kemudian ditarik kesimpulan berupa pemahaman umum yang sifatnya abstrak tentang kenyataan-kenyataan (Hadjar, 1996:33-34).

Metode yang digunakan dalam penelitian ini adalah studi kasus (case study). Artinya tarian soya-soya diangkat sebagai kasus yang diteliti di MTs Negeri Kota Ternate. Guba dan Lincoln (1985), lebih diperjelas oleh Stake (1994 dan 2005), kemudian dikembangkan oleh Creswell $(1998,2007)$ dan Dooley (2002), serta diikuti oleh Hancock dan Algozzine (2006), yang menyatakan bahwa penelitian studi kasus adalah penelitian yang dilakukan terhadap suatu 'obyek', yang disebut sebagai 'kasus', yang dilakukan secara seutuhnya, menyeluruh dan mendalam dengan menggunakan berbagai macam sumber data. Lebih khusus lagi, Stake (2005) menyatakan bahwa penelitian studi kasus bukanlah sebuah pilihan metodologis, tetapi sebuah pilihan untuk mencari kasus yang perlu diteliti. Dengan kata lain, keberadaan suatu kasus merupakan penyebab diperlukannya penelitian studi kasus.

Penelitian ini berlokasi di Madrasah Tsanawiah Negeri Kota Ternate. Lokasi penelitian adalah tempat atau sasaran dimana peneliti melakukan penelitian yakni mencari data-data dengan cara yang telah ditentukan oleh peneliti yang mengacu pada pedoman wawancara agar data yang diperoleh menjadi data yang valid dan akurat untuk dianalisis dan dipersembahkan untuk menjadi hasil suatu penelitian. (Bogdan dan Taylor, 1992:22) Waktu yang dibutuhkan dalam penelitian ini direncanakan selama dua bulan dimulai sejak 24 Maret sampai 23 Mei yang berlokasi di Madrasah Tsanawiah Negeri Kota Ternate.Subjek penelitian ini adalah Peserta Didik kelas VIII, Guru Seni Budaya Tari, Wakil Kepsek. Bidang Kesiswaan dan Kepala MTs Negeri Kota Ternate.

\section{Teknik pengumpulan dan Analisis Data}

Adapun teknik pengumpulan data dalam penelitian ini, yakni melakukan pengamatan secara langsung (observasi) terhadap objek atau sasaran yang berkaitan dengan penelitian ini guna memperoleh data awal (Arikunto, 2006). Observasi diartikan pengamatan dan pencatatan secara sistematis terhadap gejala yang tampak pada objek penelitian. Pengamatan dan pencatatan ini dilakukan terhadap objek di tempat terjadi atau berlangsungnya penelitian. (Imam, 2013:143). Teknik berikutnya adalah wawancara, yakni percakapan dengan maksud tertentu oleh dua pihak, yaitu pewawancara (interviewer) sebagai pemberi jawaban atas pertanyaan itu (Lincoln dan Guba 1985:266). Studi dokumentasi juga dilakukan, yakni instrumen yang dibuat oleh seorang peneliti untuk mendapatkan gambaran pada saat penelitian berlangsung dan sebagai pembuktian penelitian serta pelengkap data untuk mendukung data peneliti sehingga peneliti memperoleh hasil penelitian dengan baik dan ilmiah. Dalam penelitian ini, penulis melakukan kajian dan tinjauan pustaka dengan mencari teori pendukung dalam berbagai literatur melalui Observasi, interview atau wawancara dan dokumentasi untuk dianalisis menjadi hasil penelitian Renier (Gunawan Imam; 2013:175). Sedangkan, teknik analisis data yang 
digunakan peneliti adalah teknik analisis data kualitatif yang dikembangkan oleh Miles dan Huberman (1992) yaitu dengan cara reduksi data, penyajian data, verifikasi data, dan penarikan kesimpulan.

\section{PEMBAHASAN}

\section{Bentuk partisipasi peserta didik dalam kegiatan ekstrakurikuler}

Berdasarkan data yang didapatkan ketika peneliti melaksanakan penelitian terkait dengan bentuk partisipasi peserta didik dalam kegiatan ekstrakurikuler pada seni budaya tari adalah Para peserta didik diikutsertakan dalam kegiatan ekstrakurikuler dalam mengembangkan bakatnya di seni budaya tari. Guru hanya mempersiapkan atau membuat jadwal secara rutin dalam kegiatan ekstrakurikuler, misalnya dalam tarian Soya-Soya.

Selain itu juga guru seni tari mengatakan bahwa ia selalu mengikut sertakan peserta didik didalam kegiatan-kegiatan seperti kegiatan legu gam, penjemputan tamu dan acara-acara lainnya yang berhubungan dengan seni budaya Tari, dan memberikan kesempatan kepada peserta didik untuk berkreasi dalam mengikuti ekstrakurikuler di bidang seni budaya tari agar peserta didik dapat mengembangkan bakatnya. Dengan begitu peserta didik juga bisa mandiri agar kedepannya bisa menjadi lebih baik sesuai dengan kemampuan yang dimilikinya.

Dari sekian banyak, jumlah peserta didik kelas VIII yang berada di sekolah MTs Negeri Kota ternate yang jumlahnya 219 orang. Yang ikut berpartisipasi dalam kegiatan ekstrakurikuler hanya 50 orang. Hal Ini menunjukkan bahwa partisipasi peserta didik dalam kegiatan ekstrakurikuler sangat minim. Dikarenakan peserta didik kurang berminat dan kurang menyenangi kegiatan ekstrakurikuler pada seni budaya tari.

Kegiatan ekstrakurikuler mempunyai peran penting dalam mengembangkan watak dan kepribadian peserta didik. Cakupan kompetensi peserta didik yang dikembangkan dalam kegiatan ini meliputi: bakat, minat, kreativitas, kompetensi dan kebiasaan dalam kehidupan, kemampuan kehidupan keagamaan, kemampuan sosial, kemampuan belajar, wawasan dan perencanaan karir, kemampuan pemecahan masalah dan kemandirian.

Kegiatan ekstrakurikuler itu penting dapat diartikulasikan kedalam 3 lingkup pendidikan nilai (Menurut Taylor), yaitu :

a. Pendidikan nilai adalah cara terencana yang melibatkan sejumlah pertimbangan nilai-nilai edukatif, baik yang tercakup dalam manajemen pendidikan maupun dalam kurikulum pendidikan. Dari hal yang paling luas sampai yang paling sempit. Cara dapat diwakili oleh pencapaian visi dan misi untuk pengembangan nilai, moral, etika, dan estetika sebagai keseluruhan dimensi pendidikan sampai pada tindakan guru dalam melakukan penyadaran nilai- nilai pada peserta didik.

b. Pendidikan nilai adalah situasi yang berpengaruh tehadap pekembangan pengalaman dan kesadaran nilai pada peserta didik. Situasi dapat berupa suasana yang nyaman, harmonis, teratur, akrab dan tenang. Sebaliknya, situasi dapat berupa suasana yang kurang mendukung bagi perkembangan peserta didik, misalnya suasana bermusuhan, semrawut, dan acuh tak acuh. Semua situasi pendidian tersebut berpengaruh terhadap pengembangan kesadaran moral peserta didik, karena hal itu melibatkan pertimbangan-pertimbangan psikologis seperti persepsi, sikap, kesadaran dan keyakinan mereka.

c. Pendidikan nilai adalah peristiwa seketika yang dialami peserta didik. Artinya, pendidikan nilai berlangsung melaui sejumlah kejadian yang tidak terduga, seketika, sukarela, dan spontanitas. Semua tidak direncanakan sebelumnya, tidak dikondisikan secara sengaja dan dapat terjadi kapan saja. Penggalan-penggalan peristiwa seperti itu merupakan Hidden Curriculum yang dalam kasus pengalaman tertentu dapat berupa suatu kejadian kritis (critical incident) yang mampu mengubah tatanan nilai dan perilaku seseorang (peserta didik).

Secara teoritik budaya atau kebudayaan berasal dari bahasa Sansekerta yaitu 'buddhayah', yang merupakan bentuk jamak dari budhi (budi atau akal) diartikan sebagai hal-hal yang berkaitan dengan 
budi dan akal manusia. Dalam bahasa Inggris, kebudayaan disebut 'culture', yang berasal dari kata latin 'colere', yaitu mengolah atau mengerjakan. Bisa diartikan juga sebagai mengolah tanah atau bertani. Kata culture juga kadang diterjemahkan sebagai "kultur" dalam bahasa Indonesia.

Oleh karena itu,budaya adalah suatu cara hidup yang berkembang dan dimiliki bersama oleh sebuah kelompok orang dan diwariskan dari generasi ke generasi. Budaya terbentuk dari banyak unsur yang rumit, termasuk sistem agama dan politik, adat istiadat, bahasa, perkakas, pakaian, bangunan, dan karya seni bahasa, sebagaimana juga budaya, merupakan bagian tak terpisahkan dari diri manusia sehingga banyak orang cenderung menganggapnya diwariskan secara genetis. Ketika seseorang berusaha berkomunikasi dengan orang-orang yang berbeda budaya dan menyesuaikan perbedaanperbedaannya, membuktikan bahwa budaya itu dipelajari (Deddy Mulyana 2006:25).

Sejalan dengan teori yang dikemukakan oleh Thomas J. Martinek, menyebut, jika disalurkan secara efektif, kegiatan ekstrakurikuler khususnya yang berbasis fisik dapat membentuk karakter peserta didik dan secara teori dapat menyeimbangkan kemampuan anak didik baik dari sisi akademis maupun non akademis.

\section{Faktor yang menghambat partisipasi peserta didik dalam kegiatan ekstrakurikuler}

Dari hasil pengamatan dan wawancara, faktor yang menghambat partisipasi peserta didik dalam kegiatan ekstrakurikuler yaitu kebanyakan para peserta didik laki-laki yang merasa minder untuk berpartisipasi dalam kegiatan ekstrakurikuler di bidang seni budaya tari. Hal ini dikarenakan peserta didik laki-laki menganggap bahwa ekstrakurikuler pada seni budaya tari itu khususnya untuk peserta didik perempuan, sehingga peserta didik yang mengikuti kegiatan ekstrakurikuler pada seni budaya tari itu kebanyakan peserta didik perempuan.

Tujuan kegiatan dalam ekstrakurikuler dijelaskan oleh Departemen Pendidikan dan Kebudayaan (1995:2). Kegiatan ekstrakurikuler bertujuan agar:

a. Peserta didik dapat memperdalam dan memperluas pengetahuan keterampilan mengenai hubungan antara berbagai mata pelajaran, menyalurkan bakat dan minat, serta melengkapi upaya pembinaan manusia seutuhnya yang; (1) beriman dan bertaqwa kepada Tuhan Yang Maha Esa; (2) berbudi pekerti luhur; (3) memiliki pengetahuan dan keterampilan; (4) sehat rohani dan jasmani; (5) berkepribadian yang mentap dan mandiri; dan (6) memilki rasa tanggung jawab kemasyarakatan dan kebangsaan.

b. Peserta didik mampu memanfaatkan pendidikan kepribadian serta mengaitkan pengetahuan yang diperolehnya dalam program kurikulum dengan kebutuhan dan keadaan lingkungan.

Dalam bahasa Sansekerta 'seni' berasal dari kata 'sani' yang berarti: pemujaan, pelayanan, donasi, permintaan atau pencarian dengan hormat dan jujur. Hal itu berkaitan dengan kepentingan keagamaan yaitu kepentingan sesaji atau persembahan terhadap dewa-dewa. Dalam bahasa Jawa Kuno terdapat kata 'sanidya' yang artinya pemusatan pikiran. Didalam penciptaan seni tentu saja diperlukan pemusatan pikiran, tanpa pemusatan pikiran maka tidak akan tercipta seni. Tetapi ada juga yang mengatakan bahwa seni berasal dari bahasa Belanda 'genie' atau jenius. Istilah seni tersebut memberikan gambaran yang cukup jelas tentang aktivitas apa yang sekarang dibawakan oleh istilah tersebut (Kayam Umar: 1981).

Sejalan dengan itu, menurut Ki Hadjar Dewantara, Seni yaitu segala perbuatan manusia yang timbul dari hidup perasaannya dan bersifat indah, sehingga dapat menggerakkan jiwa perasaan manusia (lainnya). Definisi Ki Hajar Dewantara tersebut sejalan dengan pemikiran Leo Tolstoy yang menyatakan bahwa seni memiliki proses 'transfer of feeling', atau pemindahan perasaan dari si pencipta ke penikmat seni. Dalam hal ini seni berfungsi sebagai sarana komunikasi perasaan manusia.

Secara teori tari adalah salah satu jenis gerak selain senam, bela diri, akrobatik, atau pantomime. Sebagai seni, tari memiliki ciri-ciri yang berbeda dengan seni-seni lain. Tari adalah ekspresi jiwa manusia melalui gerak ritmis yang indah. Untuk membuat gerak yang ritmis dan indah ini perlu adanya penggarapan. Penggarapn tersebut bisa berupa stilisasi dan distorsi. Gerak yang sudah melalui proses 
penggarapan berupa gerak murni (faktor indah) dan gerak maknawi (mengandung maksud tertentu). Gerak maknawi dibagi lagi menjadi gerak Imitatif (binatang \& alam), gerak mimitif (manusia).

Faktor lain yaitu tergantung oleh sarana dan prasarana. Dimana sarana berupa alat-alat yang digunakan dalam tarian dan prasarana berupa tempat yang ada disekolah, apabila sarana dan prasarana sangat memadai maka proses partisipasi peserta didik dalam kegiatan ekstrakurikuler berjalan dengan baik. Dan seorang guru juga sebelum melaksanakan kegiatan ekstrakurikuler harus mempersiapkan jadwal dan materi-materi yang akan diajarkan supaya tujuan dalam seni budaya tari dapat diharapkan, dicapai, dan peserta didik mampu memahami materi yang diberikan oleh guru.

Selanjutnya salah satu faktor yang mempengaruhi kegiatan ekstrakurikuler seni budaya tari adalah masing-masing individu/peserta didik yang memiliki kemampuan yang berbeda-beda antara satu dengan yang lainnya, karena faktor tersebut dipengaruhi dari dalam lingkungan maupun dari luar lingkungan setiap individu maupun peserta didik. Menurut Agus S. Suryobroto (2004: 4) menyatakan sarana atau alat adalah segala sesuatu yang diperlukan dalam pembelajaran pendidikan, mudah dipindahkan dibawa oleh pelakunya atau peserta didik. Masih dalam sumber yang sama disebutkan bahwa prasarana atau fasilitas adalah sesuatu yang diperlukan dalam pembelajaran pendidikan, bersifat permanen atau tidak dapat dipindah-pindahkan.

\section{KESIMPULAN}

Berdasarkan hasil analisis data dalam penelitian ini, maka penulis dapat menarik kesimpulan sebagai berikut; (1) Bentuk-bentuk partisipasi peserta didik dalam kegiatan ekstrakurikuler pada seni budaya tari adalah Para peserta didik diikutsertakan dalam kegiatan ekstrakurikuler dalam mengembangkan bakatnya di seni budaya tari. Guru hanya mempersiapkan atau membuat jadwal secara rutin dalam kegiatan ekstrakurikuler, misalnya dalam tarian soya-soya. Peserta didik selalu berpartisipasi didalam kegiatan ekstrakurikuler seperti kegiatan Legu Gam, penjemputan tamu dan acara-acara lainnya yang berhubungan dengan seni budaya Tari. Dengan begitu peserta didik juga bisa mandiri agar kedepannya bisa menjadi lebih baik sesuai dengan kemampuan yang dimilikinya. Dari sekian banyak, jumlah peserta didik kelas VIII yang berada di sekolah MTs Negeri Kota Ternate yang jumlahnya 219 orang. Yang ikut berpartisipasi dalam kegiatan ekstrakurikuler hanya 50 orang. Hal Ini menunjukkan bahwa partisipasi peserta didik dalam kegiatan ekstrakurikuler sangat minim. Dikarenakan peserta didik kurang berminat dan kurang menyenangi kegiatan ekstrakurikuler pada seni budaya tari; (2) Faktor yang menghambat partisipasi peserta didik dalam kegiatan ekstrakurikuler yaitu kebanyakan para peserta didik laki-laki yang merasa minder untuk berpartisipasi dalam kegiatan ekstrakurikuler di bidang seni budaya tari, hal ini dikarenakan peserta didik laki-laki menganggap bahwa ekstrakurikuler seni budaya tari itu khususnya untuk peserta didik perempuan. Sehingga peserta didik yang mengikuti kegiatan ekstrakurikuler pada seni budaya tari itu kebanyakan peserta didik perempuan sarana berupa alat yang digunakan dalam tarian soya-soya yaitu ngana-ngana, salawaku dan prasarana berupa tempat untuk melakukan latihan seperti gedung Aula yang ada di sekolah. Apabila sarana dan prasarana sangat memadai maka proses dalam pelaksanaan kegiatan ekstrakurikuler berjalan dengan baik.

\section{DAFTAR PUSTAKA}

Suryosubroto, B. (2009). Proses Belajar Mengajar di Sekolah. Jakarta: PT Rineka Cipta.

Bobi, D., Mike, H. (2007). Quantum Learning Membiasakan Belajar Nyaman dan Menyenangkan, Bandung: Kaifa.

Depdiknas. (2005) Peraturan Pemerintah No. 19 tahun 2005 tentang Standar Nasional Pendidikan, Jakarta: Depdiknas.

Depdiknas, Dirjen Dikdasmen. (2006). Pendekatan Kontekstual (Contekstual Teaching and Learning-CTL), Jakarta: Direktorat Pendidikan Lanjutan Pertama.

Gordon, D \& Jeannette, V. (2008). Revolusi Cara Belajar (The Learning Revolution), bagian I dan II, Bandung Kaifa.

Ibrahim, M \& Nur, M. (2007). Pembelajaran Koomperatif. Surabaya Universiti Press. 
Puskur-BalitBang Depdiknas. (2007). Kurikulum Tingkat Satuan Pendidikan (KTSP). Jakarta: Puskur-Balitbang Silberman, M. (2002). Actife Learning. Yappendis. Yogyakarta

Sardiman, (2008). Interaksi Dan Disiplin Belajar Siswa. Dj.Rajawali Press. Jakarta.

Mardalis. (2006). Metode Penelitian Suatu Pendekatan Proposal. Bumi Aksara. Jakarta

Sagala, Syaiful (2007). Konsep Dan Makna Pembelajaran. CV. Alfabeta, Bandung.

Slameto, (2009). Belajar dan Faktor-Faktor yang Mempengaruhinya. PT Rineka Cipta. Jakarta

Muhibbin, (2005). Psikologi Belajar. PT. Grafindo Persada, Jakarta

Margono, (2005). Metode Penelitian Pendidikan. PT. Rineka Cipta, Jakarta

Surya, Muhammad. (2004). Psikologi Pembelajaran dan Pengajaran. Pustaka Bani Quraisy 